Безтелесна Л. І., д.е.н., професор, завідувач кафедри трудових ресурсів і підприємництва, Давидчук Б. Б., студентка

(Національний університет водного господарства та природокористування, м. Рівне)

\title{
ЯКІСТЬ ЖИТТЯ ПРАЦІВНИКІВ ЛЕГКОЇ ПРОМИСЛОВОСТІ УКРАЇНИ: ОЦІНКА ТА УМОВИ ЗАБЕЗПЕЧЕННЯ
}

Розкрито зміст поняття «якість життя». Доведено, що якість життя працівників легкої промисловості забезпечується реалізацією бізнес-стратегії. Зазначено, що функціонування легкої промисловості в Україні відбувається переважно на засадах аутсорсингу. Відображено країни аутсорсери та бренди, що відшиваються в Україні. Наведено соціально-демографічна структура працівників легкої промисловості та розмір їх середньомісячної заробітної плати та у країнах-постачальниках давальницької сировини до України. Визначено, що якість життя працівників легкої промисловості в Україні є низькою. Запропоновані заходи, реалізація яких забезпечить підвищення якості життя працівників легкої промисловості в Україні.

Ключові слова: якість життя, працівники, соціально-демографічна структура, середньомісячна заробітна плата, аутсорсинг, бренд, давальницька сировина.

Постановка наукової проблеми та її значення. Якість життя працівників $є$ складним поняттям і здебільшого застосованим для характеристики суспільства. Разом з тим, висока якість життя сприяє розвитку соціально-економічних відносин, раціональному використанню людського потенціалу працівників, що задіяні в економіці, зокрема, і в легкій промисловості. Проте, параметри розвитку людського потенціали та можливостей його ефективної реалізації зумовлюються зовнішніми факторами серед яких основне місце посідає місце та умови праці, які в основному формує роботодавець.

Огляд наукових джерел. У науковій літературі існують різні підходи до оцінювання якості життя. Так, якість життя порівнюється з певними нормативами соціальних стандартів (Колот А.М. [5]), $є$ інтегральним показником, який вимірюється сукупністю комплексних характеристик економічних і неекономічних факторів (Адамчук В.В. [1], Попов І.С. [6]) або ж то зовсім не має ніяких одиниць виміру чи систематичних показників (Тоффлер 0. [7]). Якість життя розглядається як результат економічного і політичного розвитку країни (Боб- 
ков В., Мстиславський П., Завіновська Г.Т. [4]) або з позиції індивіда, де розуміння якості життя зводиться до суб'єктивних відчуттів і уявлень особистості про власний добробут (Єсінова Н.Г. [3]).

Постановка наукової проблеми. Незважаючи на велику кількість наукових праць, присвячених якості життя, недослідженими залишаються умови забезпечення якості життя працівників, зокрема окремих видів економічної діяльності, а саме легкої промисловості. Якість життя працівників забезпечується у результаті організації та функціонування саме бізнес-стратегії певної галузі промисловості. Розкриття умов організації та діяльності легкої промисловості в Україні, її специфіки у формуванні виробничої програми та пошуку ринкової ніші у глобальній економіці, особливостей налагодження партнерських стосунків, функціонування виробництва $€$ передумовою до забезпечення якості життя працівників. Саме й це стало завданням даної статті.

Виклад основного матеріалу. У змісті поняття «якість життя» відображені всі сторони життя суспільства, які безпосередньо підпадають під вплив економічних, соціальних, політичних та ідеологічних законів суспільного розвитку. Загалом, поняття «якість життя» можна охарактеризувати як комплексну інтегральну оцінку, яка розробляється на основі системи показників, що враховують весь спектр дії основних чинників (як суб'єктивних компонент, так і об'єктивних факторів).

Важливим для України є підняття життєвого рівня населення та забезпечення якості його життя.

Проте, забезпечення вище згаданого вимагає ресурсів, які створюються у реальному секторі економіки. Зокрема, інтерес привертає забезпечення якості життя працівників легкої промисловості, які долучені до задоволення споживчого попиту на товари першої необхідності, а саме одягу та взуття.

Отож, у легкій промисловості України залучено понад 220 тисяч осіб. Майже вся вироблена продукція експортується, а на теренах України все частіше розміщуються виробництва відомих західних брендів. Частка замовлень, розміщених світовими брендами одягу на українських підприємствах, в останні роки зростає. За експертними оцінками, питома вага експорту становить від $80 \%$ до $90 \%$ всієї виробленої на фабриках продукції.

Більшість підприємств легкої промисловості (понад 80\%) в Україні працюють за так званою давальницькою схемою: отримують від відомого західного бренду або його підрядника замовлення, тканини, викрійки та фурнітуру, а самі займаються лише пошиттям. 3 цих підприємств лише 9,2\% отримують сировину і матеріали від вітчизняних замовників. Це поширена практика світового аутсорсвиробництва. 
Привабливим для виробників західних брендів одягу та взуття в Україні $\epsilon$ географічна близькість порівняно з азійськими виробниками, діюча інфраструктура у вигляді фабрик, побудованих ще в радянські часи, досить хороша кваліфікація робітників. Але головним аргументом залишається заробітна плата, яка після девальвації гривні в 2014-2015 роках залишається найнижчою в Європі.

Згідно з офіційними даними, середня заробітна плата у сфері виробництва одягу і взуття була найнижчою з усіх галузей промисловості - в 2017 році вона становила 187 євро. Показово, що оплата праці в швейній галузі України $€$ в рази нижчою ніж в країнахаутсорсерах (рис. 1).

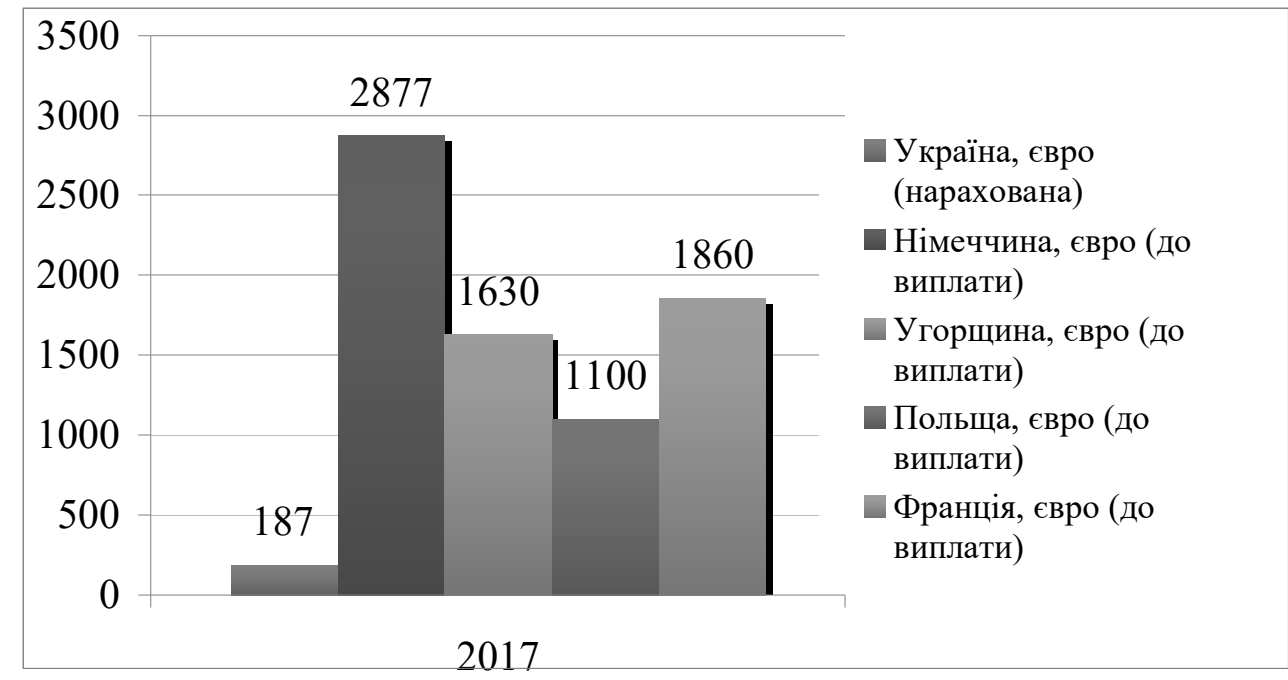

Рис. 1. Середньомісячна заробітна плата в швейній промисловості в Україні та країнах давальницької сировини [8]

Вітчизняним підприємствам легкої промисловості закордонні компанії передають окремої функції (бізнес-процесів) на договірній основі, тобто, працюють за схемою аутсорсингу. Але так це поняття звучить для підприємства-замовника (аутсорсера).

В Україні дане поняття все частіше зустрічається як «толінг» або ж то виробництво за давальницькою схемою.

Перевагами аутсорсингу (толінгу) для замовника є: 1) доступ до діючої (сформованої) інфраструктури; 2) економія власних ресурсів, зниження собівартості продукції (за рахунок «дешевої» робочої сили); 3) отримання послуг високої якості (на основі підвищеної відповідальності переробника); 4) концентрація зусиль на інших бізнеспроцесах. Недоліки: ризик неякісного виконання доручених функцій; ризик невиконання функцій; ризик порушення конфіденційності комерційної таємниці; імовірність зниження управлінської гнучкості підприємства-переробника.

Перевагами аутсорсингу (толінгу) для переробника є: 1) імідж 
замовника «працює» на переробника; 2) переймання досвіду, доступ до прогресивних технологій; 3) можливість завантаження власних виробничих потужностей; 4) відсутність необхідності маркетингу; 5) мінімізація ризиків, надійність та стабільність. Недоліки: 1) висока відповідальність; 2) занижена рентабельність; 3) втрата потенційного прибутку (левову частину прибутку після реалізації продукції одержує власник сировини); 5) експлуатація людських ресурсів.

Тобто, аутсорс-виробництво дає право зекономити на собівартості виробу за рахунок «дешевої» робочої сили, маючи при цьому невеликі ризики та можливості зосередження на інших процесах.

Переважна більшість працівників фабрик з виробництва одягу та взуття в Україні - жінки, середній вік яких становить 45 років (рис. 2). Це досить нетипово, якщо порівнювати з аутсорсинговим виробництвом в азіатських країнах, де його нерідко критикують за використання дитячої праці.
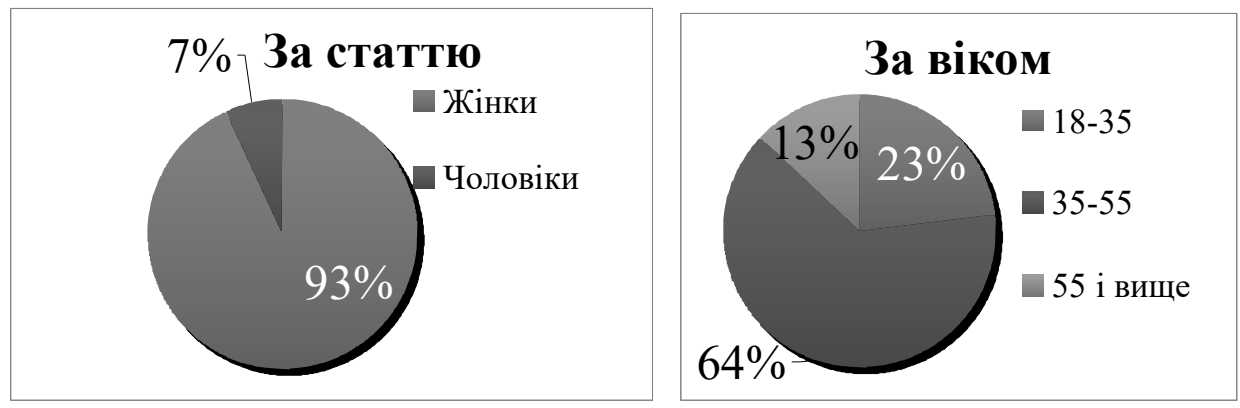

Рис. 2. Соціально-демографічна структура працівників швейної промисловості в Україні [8]

Економічна криза, що існує, дискримінація за віком, зазвичай, не дають працівницям знаходити гідну альтернативу роботі на швейних фабриках. Робота прибиральницями, продавцями або навіть в приватних швейних ательє, як правило, не приносить працівникам велику соціальну захищеність.

Низька заробітна плата, яку отримують працівники фабрик, що працюють на давальницькій сировині унеможливлює купівлю ними нового одягу, який вони самі шиють, навіть масових європейських брендів. Одягаються працівники переважно в секонд-хендах або на дешевих ринках.

Працівники даної галузі змушені максимально скорочувати всі витрати. Наслідками є неякісне харчування та погіршення стану здоров'я. Багато працівників та членів їхніх сімей займаються городництвом, щоб прогодувати себе, отримують державні субсидії на воду та електроенергію, а також пенсії за віком чи інвалідністю [8].

У Міжнародній організації по захисту прав працівників легкої 
промисловості (Clean Clothes Campaign) покладають основну відповідальність за жебрацький рівень життя українських робітниць на західну фешн-індустрію. Саме західні бренди стоять на вершині цього виробничого ланцюжка [2].

За даними звіту Clean Clothes Campaign в Україні виробляють одяг для наступних брендів: Asos, Adidas, Benetton, C\&A, Esprit, Hugo Boss, Inditex/Zara, Kirsten, Liz Claiborne, Mexx, Marks \& Spencer, Mart Visser, Next, Oui, Peek \& Cloppenburg, Steps, s.Oliver, Saint James, Topshop, Triumph, Tommy Hilfiger/PVH, Walbusch.

Міждержавна структура експорту легкої промисловості України наступна: Німеччина - 37\%, Угорщина-7\%, Польща-7\%, Румунія, Франція та Данія мають по 6\% кожна.

Що ж стосується взуття, то тут картина дещо інша: перше місце (32\%) займає Румунія, далі йдуть Польща (19\%), Італія (14\%), Росія (13\%) і Угорщина (8\%).

Історично аутсорсинг уперше був визнаний як бізнес-стратегія у 1989 році, хоча інструментарій аутсорсингу був використаний набагато раніше протягом 70-х років в автомобілебудівній галузі. Регулярно застосовуваний протягом 90-х, інструмент аутсорсингу міцно інтегрувався в міжнародний бізнес [10].

Аутсорсинг людських ресурсів, яким на даний час в повній мірі користуються закордонні брендові компанії, переносячи свої виробництва на територію із «дешевою» робочою силою широко розповсюджений на теренах нашої країни, що в підсумку формує низьку якість життя працівників легкої промисловості.

Висновки та пропозиції. Робота вітчизняних підприємств легкої промисловості за давальницькою сировиною із зарубіжними партнерами за схемою аутсорсингу дає можливість створювати робочі місця населенню, тобто формувати зайнятість, а відтак трудові доходи. Проте, низький рівень заробітної плати у легкій промисловості забезпечує й низьку якість життя працівників, що є наслідком, як на підприємницькому рівні, невміння вести рівні партнерські стосунки, ділові переговори, а також умовами, які склалися в державі, зокрема, низьким рівнем соціальних гарантій, що і породжує бідність серед зайнятого населення.

Тому аутсорсинг, як інструмент ведення бізнесу в Україні, спричиняє низьку якість життя працівників саме легкої промисловості, що підтверджено міжнародними дослідженнями [2; 8; 9] та обґрунтовано в цій роботі.

Наслідками зайнятості працівників у легкій промисловості є: неякісне харчування; погіршення стану здоров'я; вимушене ведення городництва; звернення за державними субсидіями; оформлення 
пенсій за віком та інвалідністю; забезпечення себе одягом із секондхендів та дешевих ринків; жебрацький характер життя.

Підвищення якості життя працівників легкої промисловості в України вимагає: удосконалення галузевих підходів до формування ціни на здійснення толінгових операцій; розвитку умінь налагодження ділових стосунків та ведення переговорів; підвищення і забезпечення соціальних гарантій на рівні європейських країн; законодавче регулювання аутсорсингу на основі жорсткого контролю; переорієнтації на самостійне виробництво конкурентоспроможної на міжнародному ринку продукції легкою промисловістю України.

1. Экономика труда : учебник / В. В. Адамчук, Ю. П. Кокин, Р. А. Яковлев ; под ред. В. В. Адамчука. М. :ЗАО «Финстатинформ», 1999. 431 с. 2. В Украине шьют ВСЕ люксовые бренды, причем на экспорт. В 4 раза дешевле, чем В Китае! https://leprechaun.land/v-ukraine-shyut-vse-lyuksovye-brendyprichem-na-eksport-v-4-raza-deshevle-chem-v-kitae/?fbclid=IwAROVTXpx81GIrF69rFJSeXZuRVc6PJpWcjQMktwjEvL6nr2K3Tlp9lywL4 (дата звернення: 15.01.2019). 3. Єсінова Н. І. Економіка праці та соціально-трудові відносини : навчальний посібник. К. : Кондор, 2004. 432 с. 4. Бобков В., Мстиславский П. Качество жизни: сущности и показатели. Человек и труд. 1996. № 6. С. 76-79. 5. Колот А. М. Соціально-трудові відносини: теорія і практика : монографія. К. : КНЕУ, 2003. С. 74. 6. Попов С. И. Проблема качества жизни в современной идеологической борьбе. М. : Политиздат, 1977. 7. Тоффлер 0. Третья волна. М., 2003. 8. Умови та оплата праці в українському швейному секторі, який шиє для західних брендів: URL: https://www.academia.edu/35334280/Умови_та_оплата_праці_в_українсько му_швейному_секторі_який_шиє_для_західних_брендів (дата звернення: 15.01.2019). 9. Ціна брендів: Дослідження Clean Clothes Campaign на фабриках України URL: https://womo.ua/tsina-brendiv-doslidzhennya-cleanclothes-campaign-na-fabrikah-ukrayini/ (дата звернення: 15.01.2019). 10. Википедия / статья: Аутсорсинг, 30.01.2009: URL: http://ru.wikipedia.org/wiki/D0\%B3 (дата звернення: 15.01.2019).

\section{REFERENCES:}

1. Ekonomika truda : uchebnik / V. V. Adamchuk, Yu. P. Kokin, R. A. Yakovlev ; pod red. V. V. Adamchuka. M. : ZAO «Finstatinform», 1999. 431 s. 2. V Ukraine shiut VSE liuksovye brendy, prichem na eksport. $\vee 4$ raza deshevle, chem $v$ Kytae! https://leprechaun.land/v-ukraine-shyut-vse-lyuksovye-brendyprichem-na-eksport-v-4-raza-deshevle-chem-v-kitae/?fbclid=IwAROVTXpx81GIrF69rFJSeXZuRVc6PJpWcjQMktwjEvL6nr2K3Tlp9lywL4 (data zvernennia: 15.01.2019). 3. Yesinova N. I. Ekonomika pratsi ta sotsialno-trudovi vidnosyny : navchalnyi posibnyk. K. : Kondor, 2004. 432 s. 4. Bobkov V., Mstislavskii P. Kachestvo zhizni: sushchnosti i pokazateli. Chelovek i trud. 1996. № 6. S. 76- 
79. 5. Kolot A. M. Sotsialno-trudovi vidnosyny: teoriia i praktyka : monohrafiia. K. : KNEU, 2003. S. 74. 6. Popov S. I. Problema kachestva zhizni v sovremennoi ideolohicheskoi borbe. M. : Politizdat, 1977. 7. Toffler O. Tretia volna. M., 2003. 8. Umovy ta oplata pratsi $v$ ukrainskomu shveinomu sektori, yakyi shyie dlia zakhidnykh brendiv:

URL: https://www.academia.edu/35334280/Umovy_ta_oplata_pratsi_v_ukrainskom u_shveinomu_sektori_yakyi_shyie_dlia_zakhidnykh_brendiv (data zvernennia: 15.01.2019). 9. Tsina brendiv: Doslidzhennia Clean Clothes Campaign na fabrykakh Ukrainy URL: https://womo.ua/tsina-brendiv-doslidzhennya-cleanclothes-campaign-na-fabrikah-ukrayini/ (data zvernennia: 15.01.2019). 10. Vykypedyia / statia: Autsorsynh, 30.01.2009: URL: http://ru.wikipedia.org/wiki/D0\%B3 (data zvernennia: 15.01.2019).

Beztelesna L. I., Doctor of Economics, Professor, Head of the Department of Labor Resources and Entrepreneurship, Davydchuk B. B., Senior Student (National University of Water and Environmental Engineering, Rivne)

\section{QUALITY OF LIFE OF UKRAINE'S LABOR INDUSTRY WORKERS: ASSESSMENT AND CONDITIONS OF PROVIDING}

The content of the concept of "quality of life" is disclosed. It is proved that the quality of life of light industry workers is ensured by the implementation of the business strategy. It is noted that the functioning of light industry in Ukraine is mainly based on outsourcing. Reflected countries outsourced and branded in Ukraine. The socio-demographic structure of light industry workers and the size of their average monthly wages and in the countries that supply raw materials to Ukraine are given. It is determined that the quality of life of light industry workers in Ukraine is low. Measures are proposed, the implementation of which will improve the quality of life of light industry workers in Ukraine.

Keywords: quality of life, employees, socio-demographic structure, average monthly wage, outsourcing, brand, raw material for giving.

Безтелесна Л. И., д.э.н., профессор, заведующая кафедрой трудовых ресурсов и предпринимательства, Давыдчук Б. Б., студент (Национальный университет водного хозяйства и природопользования, г. Ровно) 


\section{КАЧЕСТВО ЖИЗНИ РАБОТНИКОВ ЛЕГКОЙ ПРОМЫШЛЕННОСТИ УКРАИНЫ: ОЦЕНКА И УСЛОВИЯ ОБЕСПЕЧЕНИЯ}

Раскрыто содержание понятия «качество жизни». Доказано, что качество жизни работников легкой промышленности обеспечивается реализацией бизнес-стратегии. Отмечено, что функционирование легкой промышленности в Украине происходит преимущественно на основе аутсорсинга. Отражено страны аутсорсеры и бренды, которые отшиваются в Украине. Приведены социальнодемографическая структура работников легкой промышленности и размер их среднемесячной заработной платы и в странахпоставщиках давальческого сырья в Украину. Определено, что качество жизни работников легкой промышленности в Украине является низкой. Предложенные меры, реализация которых обеспечит повышение качества жизни работников легкой промышленности в Украине.

Ключевые слова: качество жизни, работники, социальнодемографическая структура, среднемесячная заработная плата, аутсорсинг, бренд, давальческое сырье. 